\title{
The study on Construction of Innovative Teaching team for computer application platform Under Complete Credit System
}

\author{
Sheng Liu ${ }^{1, a}$ Xiaoming You ${ }^{1, b}$ \\ ${ }^{1}$ School of Management, Shanghai University of Engineering Science, Shanghai201620, China; \\ ${ }^{2}$ Department of Computer, Shanghai University of Engineering Science, Shanghai201620, China. \\ als6601@163.com, byxm6301@163.com
}

Keywords: Complete Credit System; Computer application platform; Teaching team; Innovative ability.

\begin{abstract}
With the continuing reform of higher education system and further refinement, the construction and optimization of complete credit system has become a hot spot in higher education theory and practice, teaching team building is one of the focus points of the complete credit system construction. The various disadvantages in the construction of teaching team for computer application platform under the current credit system have been analyzed and discussed. Then, several improved methods for teaching team building are discussed. Practice shows that this mode will improve students' creative abilities, spirit of cooperation training and ability to adapt to society.
\end{abstract}

\section{Introduction}

The reform of credit system in colleges and universities has been proposed from China's ministry of education since 1978, the mode of the credit system gradually transition from the academic year to complete credit system[1]. At the same time, with the rapid development of computer and application technology, computer technology has become an important part of knowledge structure in contemporary college students. The process of social informationization has led to the reform of college education must be injected into the new element--"training and improving the students ability to learn through computer and multimedia courseware, and the ability of using network resources to learn ","encouraging students to learn actively and independently by the means of information, improving students' ability to analyze and solve problem by the use of information technology"[2]. So, the status of computer application ability training in the management subject has a fundamental change, it is not only professional training requirements of the information management and information system, but also professional training requirements of the relevant major such as logistics management, marketing, finance, engineering management and other[3].

Under this background, in order to meet the need of non major students to select a series of computer courses after implement the credit system, it has been become new target to build an excellent teaching team for computer application platform core curriculum to meet the need of computer application technology reform and development for the management professional.

The research on the teaching team construction for computer application platform core curriculum has important significance. It is conducive to reform the credit system, to improve the teaching quality and the talents training, to promote school discipline construction, conform to the trend of education reform, to meet the demands of the era graduates etc.

\section{Research status analysis for teaching team building under complete credit system}

Complete credit system is a teaching management system based on the elective system, by which students can graduate with a certain degree of credit. The core of the study is to choose the subjects, the course and the learning process independently. The essence of complete credit system is a management system which makes knowledge modularized to cultivate students. Compared with the traditional academic year credit system, the complete credit system requires that the computer platform course must take into account not only the students' curriculum study to obtain the 
appropriate credits by mastering useful knowledge, but also the students' information literacy ,which is "application oriented and outstanding practice", in order to ease the employment pressure. "Diversified, modular, integrated, network" will become the new target and development trend of computer platform course teaching[4].

Nowadays, computer teaching platform belongs to department of Information management and system. The main courses of the teaching team include computer information technology, advanced language program design, the advancement of high-level language program design, data structure, object oriented programming, system model and simulation, database principle and application, modern intelligent information processing etc. But there are still some demerits existed just as below:

\subsection{Focus on macro-study, ignore micro-study}

The implementation of complete credit system is not only an inevitable requirement for the reform of the educational system and the personnel training mode in higher education, but also a challenge to the existing teaching management system and mode. Complete credit system is required to change the original teaching organization form, examination and evaluation method, etc., and to establish a diversified, flexible teaching organization form and management mode.

However, due to the subjective reasons, we have a research on the construction of teaching team, with no operational research result, which is still in the macro framework, totally neglecting the study on the micro level. The research concerning the concept, importance, strategies, problem of the construction of teaching team is very deep, but no more specific measures. For example, how to explore the modern information management system and teaching material in line with the requirements of different professional disciplines, scientific, reasonable and economic and so on[5].

\subsection{Center on theory teaching, lack of creative practical teaching, fail to band theory teaching} with practical teaching perfectly

The purpose of computer teaching platform is to develop and enhance the ability to learn knowledge from the computer and multimedia courseware, network resource and encouraging students to study actively and independently via information[6]. These courses are mostly the combination of theory and practice. Although we have made adjustment and reform to the condition that traditional teaching practice containing less practical teaching, for different majors and subjects, the study of specific teaching practice is not enough and the mutual penetration of theory and practice teaching does not achieve the ideal state. The general teaching process is carrying out the corresponding theoretical teaching firstly, and then interpreting the connotation of the theory through the experimental teaching, with less innovative experimental project. Experimental study for most students is tasted, no in-depth inquiry, the result is lacking of creativity.

In general, after accepting practice teaching contents, a part of students can vaguely understand the meaning of the corresponding theory, but the majority of students cannot master this content within a short period. In accordance with the progress of teaching and the next part of the theory and practice will be carried out, the majority of students have no learning enthusiasm and are stagnated, which will have the direct impact on teaching effect.

\subsection{Teaching case does not link with related professions tightly}

Complete credit system is a teaching management system respecting the students' individual development, which is to implement the elective system, the flexible system and the target management. Therefore, the teaching resources of the computer platform should also be diversified and as far as possible adapt to the differences of personality and learning style of the students. For each student, it will provide the suitable teaching case, the independent learning method and the cooperative learning, so that teachers and students can use the teaching resources to carry out various teaching and learning activities.

However, in the teaching process, most teachers just follow the examples of teaching materials and main points of knowledge to complete the teaching task. Few of them can combine the different application cases and the computer knowledge to explain for students according to the different category. 
For example, with the advent of the global information, knowledge economy and the rapid development of social economy via modern science and technology, the position of the database application technology in the management disciplines has changed fundamentally. Database application technology is not only the major course of information management and information system, but also an important course of relevant majors, such as logistics management, marketing, finance, engineering management, international economy and trade. Database application technology is the key technology to develop the talents who is good at managing, marketing, financing and trading[7,8]. In the teaching process, teachers seldom explain the different professional database application examples with the curriculum knowledge of database according to different professional categories. So that students can not see the specific application of database technology and it is difficult to attract the students' attention. In addition, the target of studying "database principle and application" of is not clear. Therefore, it is necessary to use different experimental teaching cases and teaching methods to mobilize students' learning enthusiasm and promote students' learning.

\section{The constructive goals and measures of teaching team}

\subsection{The constructive goals of teaching team}

The teaching team will take the research as the carrier based on teaching, the combination as a support, and further accelerating the pace of the reform of the curriculum system and teaching content, optimizing the teaching resources, reforming education mode, and striving to improve the level and quality of teaching team. The team will always adhere to the talent training as the lifeline, improving the quality of personnel training as the goal, improving the overall quality of teachers as the core, cultivating high quality applied talents with strong social responsibility and sustainable development as a breakthrough, we still adhere to the quality improvement as the core, striving to build a team which is not merely reasonable and qualified but suitable for computer technology reform and developing needs.

\subsection{The construction measures of teaching team}

According to the feature of the applied undergraduate colleges, teaching team will break the original teaching method, implement the bold reform and combine teaching with practice, and then we set up a systematic training platform from the perceptual knowledge training course to provide for innovative design conditions, make the teaching content advanced, scientific and can reflect the latest technological achievements in the field of computer science timely; At the same time, we use advanced teaching methods, means and teaching mode, construct teaching resource database actively and use network platform to achieve a high quality teaching resources of sharing, to make it to get better teaching effect.

\subsubsection{The construction of teaching material system and teaching system with distinct application characteristics}

According to the latest development of computer science and technology and rely on the principle of broadening base, improve ability and pay attention to the application, the teaching team have edited some books for applied undergraduate colleges and universities such as Computer Information Technology, High Level Language Programming, Data Structure and Program Design, Principle and application of database system, Computer network theory and application, and so on, which are based on the analysis of advantages and disadvantages of related teaching materials at home and abroad, summarizing teaching experience for many years. It will make up for the domestic tutorial either "heavy theory light practice", or "light theory heavy practice"; at the same time, we have edited Java language programming practice and ASP.NET application design, which have combined the database technology and object-oriented technology with WEB 2.0 technology organically, to adapt to the innovative interdisciplinary, applied and entrepreneurial talent training requirements, and form teaching materials of modern information management system with distinct application characteristics. 
At the same time, the teaching team has reformed the teaching content, method and means deeply. We have further systematically studied about the teaching target, teaching program, teaching content, teaching strategy and media auxiliary way, and then revise and improve the course syllabus, the teaching outline, experiment instruction and some others. Besides, the modern information management course teaching system has been explored to meet the demand of applied undergraduate colleges and universities for different professional, scientific and reasonable, complete structure and economic performance.

\subsubsection{The teaching mode and teaching method reform practice with "Unify basic theory, vary different professional case"}

In the teaching process, the content of the course is fully adjusted to integrate and improve, focusing on the "three basic" (basic knowledge, basic principles, basic skills) and the "three core" (program design, database development, web application), we have explored the classification of teaching mode; strengthen the integration of the relevant professional, and the knowledge system based curriculum construction. Therefore, according to the different nature, characteristics and the learning object of applied undergraduate colleges, the teaching team have designed and wrote varying related professional case of teaching, for instance, accounting management, financial management, logistics management, tourism management, business management, industrial engineering, project management, human resources management, finance and so on. And then attempt to reform based on the "Unify basic theory, vary different professional case ". The traditional teaching concept has been changed; the teaching content of the course has been further optimized and integrated. Further, combine the curriculum study and the cultivation of students' professional ability, the enthusiasm and initiative of students learning have fully mobilized. We have got a good teaching effect, and published high quality research papers in the core journals and International Conference[9].

\subsubsection{The design and construction of the multi-level and three-dimensional experimental teaching platform}

Because of the characteristics of the computer course is emphasis on theory and practice, the content changes quickly, the practice platform is required high level, and the teaching method is demanded variety. In the course of teaching, the teaching mode of curriculum practice (experiment) has been reformed in order to keep up with the development of computer technology, and the multi level and three - dimensional experimental teaching platform has been formed, include: experiment on machine, integrated curriculum design under the guidance of professional, innovative experimental projects, etc, which combined with theoretical knowledge teaching system to form the advanced application innovative talents training system to meet the social needs.

At the same time, teaching team focus on real-time teaching content, the long-term research, development experience and teaching results is imparted to students, to further optimize the teaching content, in order to improve the students' computer practice ability and innovation ability gradually[10].

\subsubsection{The design and development of Computer Assisted Instruction platform}

In the course of the teaching, from the actual needs of the current domestic and abroad school work management, network teaching platform based on ASP.NET has been designed and implemented based on Visual Studio2010 and Microsoft SQL Server2008. At present, online intelligent testing system, online communication, discussion and consultation system are completed.

The realization of the system makes the communication between students and teachers more convenient and flexible. It provides students and teachers with the modern teaching platform. It expands the space of teachers and students. And it has great realistic meaning, which improves the students' learning efficiency and teachers' working efficiency greatly.

\subsubsection{The construction of network teaching platform with rich teaching resource}

We have further improved the course website construction, and constantly opened up new space for the network study, established a more complete online Q \& A, online job transfer and correction, online practice, online information query system. 
In the course of the teaching, by using "Curriculum Center" software, the teaching platform with "information comprehensive, first-class service" is constructed, which includes curriculum objectives, curriculum features, teaching methods, teaching plans, teaching contents, students' homework, exercises and answers and so on, so that the students can prepare and review their work through the Internet.

\section{Conclusion}

After several years of teaching reform and practice, the team plays an important role in cultivating students' ability of autonomous learning, teamwork spirit and comprehensive use of knowledge to analysis and solve practical problems, improving students' entrepreneurial quality, and have achieved remarkable results.

In recent three years, professional students have participated in the national high school mathematics modeling contest and have won two national second prizes, three Shanghai first prizes, five Shanghai second prizes and five Shanghai third prizes, and have won many award in all kinds of college students in computer application award winning competition. At the same time, the teaching team continues to grow and expand, at present, we have a professor, three associate professors and two lecturers, and have formed a strong teaching team, has achieved fruitful teaching and scientific research in recent years.

\section{References}

[1]. Ministry of education, "national medium and long term educational reform and development plan(2010-2020 )[DB/OL],” http://www.gov.cn/jrzg/2010-07/29/content_1667143.htm.

[2]. Ministry of education Colleges and Universities Computer Foundation Course Teaching Guidance Committee, “Colleges and Universities Computer Foundation Teaching Development Strategy Research Report (teaching basic requirements of the basic computer course),” Beijing: Higher Education Press, 2009.

[3]. J.H. Wu, W.G. Lu, H.L. Meng, “2010 ETP/IITA 2010 International conference on Management,” China: Science and Engineering, 2010.

[4]. S.C. Zhang, "Research on the construction of teaching team in Colleges and universities of China, ” Chengdu: University of Electronic Science and technology of China, 2010.

[5]. H.B. Wang. "Research on the teaching content of mechanical electronics under the credit system,” Curriculum education research, 2012, (2).

[6]. J.W. Xia, L.H. Zhang, "The construction of teaching team as the starting point to overall promote innovative talents cultivation,” China's higher education. 2010,(9),pp.37-38.

[7]. X.H. Meng, "Research on the experimental teaching mode for information management professional database,” Computer education, 2011, vol.1,pp. 60-64.

[8]. X. Ye, J.S. Li, H.L. Li, “Teaching reform of database principle and application practice," Computer education, 2011, vol.1, pp. 56-59.

[9]. S. Liu, Y.M. Wang, “Study on the reform of teaching mode for management subject," Research on the development of education, 2010, vol.11 (Suppl), pp.1-2.

[10]. Y.Z.YANG, J.B. JIANG, G.C.WANG, "Reform and Practice on Experimental Teaching Based on Collaborative Innovation,” Research and Exploration in Laboratory, 2016, vol.35, no.1, pp.173-175. 